\title{
The Sertoli Cell - A Hormonal Target and 'Super' Nurse for Germ Cells That Determines Testicular Size
}

\section{Cecilia Petersen Olle Söder}

Paediatric Endocrinology Unit, Department of Woman and Child Health, Astrid Lindgren Children's Hospital, Karolinska Institutet, Stockholm, Sweden

\section{Key Words}

Sertoli $\cdot$ Testis - Testicular dysgenesis syndrome ·

Endocrine $\cdot$ Paracrine

\begin{abstract}
The somatic Sertoli cell plays an essential role in embryonic determination of male somatic sex and in spermatogenesis during adult life. One individual Sertoli cell supplies a clone of developing germ cells with nutrients and growth factors and it is well established that the number of Sertoli cells present is closely correlated to both testicular size and sperm output. Sertoli cells continue to proliferate and differentiate until the beginning of puberty, when they cease dividing and start nursing the germ cells. At this point in time, the future capacity of the testis for sperm production has thus been determined. Prior to puberty the Sertoli cells are immature and differ considerably with respect to morphology and biochemical activity from the mature cell. The several investigations that have focused on hormonal and paracrine regulation of the functions of the mature cell are reviewed here, but the mechanisms underlying the maturation and general maintenance of well-functioning Sertoli cells remain obscure. An alarming decline in male reproductive health has been observed in several Western countries during recent decades. Disturbance of Sertoli cell differentiation is
\end{abstract}

thought to be involved in the pathogenesis of both a poor sperm count and testicular cancer. It is speculated that environmental agents that disrupt the estrogenic/androgenic balance in the testis may play a role in this connection.

Copyright $\odot 2006$ S. Karger AG, Basel

\section{Introduction}

The testicle performs two major tasks: the production of testosterone and formation of haploid germ cells (spermatogenesis). These functions are generally considered to be regulated by pituitary gonadotrophins, with luteinizing hormone (LH) acting on the testosterone-producing Leydig cells located in the interstitium and folliclestimulating hormone (FSH) affecting Sertoli cells in the seminiferous tubules.

Originally described by Enrico Sertoli in 1865, the somatic Sertoli cell fills a crucial nursing function in connection with spermatogenesis. Comprising the structural elements of the seminiferous epithelium, fully differentiated Sertoli cells regulate the flow of nutrients and growth factors to the haploid germ cells by tight junctions between adjacent cells in this epithelium. This so-called blood-testis barrier (fig. 1B) thus does not separate the blood from testicular tissue, but rather constitutes a deli-

\section{KARGER}

Fax +4161306 1234 E-Mail karger@karger.ch www.karger.com

\section{(C) 2006 S. Karger AG, Basel}

0301-0163/06/0664-0153\$23.50/0

Accessible online at:

www.karger.com/hre
Cecilia Petersen, $\mathrm{MD}, \mathrm{PhD}$

Pediatric Endocrinology Unit (Q2:08)

Astrid Lindgren Children's Hospital, Karolinska University Hospital

SE-171 76 Stockholm (Sweden)

Tel. +4685177 7323, Fax +4685177 5128, E-Mail Cecilia.Petersen@ki.se 
Table 1. Some proteins expressed by immature and mature Sertoli cells*

\begin{tabular}{lll}
\hline Protein & $\begin{array}{l}\text { Immature cells } \\
\text { (prior to } \\
\text { puberty) }\end{array}$ & $\begin{array}{l}\text { Mature cells } \\
\text { (from puberty } \\
\text { onwards) }\end{array}$ \\
\hline Cytokeratin & + & - \\
Transferrin & - & + \\
Interleukin-1 $\alpha$ & - & + \\
Androgen receptor & $(+)$ & + \\
Anti-Müllerian hormone & + & - \\
Aromatase & + & - \\
Inhibin $\beta$ B-subunit & + & - \\
\hline
\end{tabular}

* For additional information, see $[86,96]$.

cate boundary between diploid and haploid germ cells. Accordingly, a well-functioning Sertoli cell provides the developing germ cells with appropriate mitogens, differentiation factors and sources of energy, as well as protecting them from harmful agents and from the host's own immune system [1].

Clearly, the rate and quality of spermatogenesis is determined directly by the number and function of Sertoli cells present. Consequently, testicular size is frequently employed as a crude indicator of Sertoli cell number. Several of studies have focused on the regulation of the proliferation and the differentiated function of this cell type.

In the late 1990s a disturbing phenomenon directs a spotlight onto Sertoli cell development. Several investigations revealed an increase in disturbed male reproductive health, a condition referred to by Skakkebaek et al. [2] as testicular dysgenesis syndrome (TDS). TDS includes a number of different phenomena, i.e., retentio testis, hypospadia, reduced sperm count and testicular cancer, the frequencies of all of which were shown to be increasing in several regions of the world (see references in [2]). Malfunctioning and poorly developed Sertoli cells are suggested to be involved in the pathological processes leading to a reduction in the quality of semen, as well as to testicular cancer.

\section{Sertoli Cell Development}

The first appearance of fetal Sertoli cells in the primitive gonad defines the initial stage in the development of the embryonic testis. These cells express the sry gene, thus determining the male sex of the gonad. As the exclusive source of anti-Müllerian hormone Sertoli cells are also responsible for inhibiting the development of internal female genitalia. These cells together with another type of somatic testicular cell, the peritubular cell, are required for formation of the testis cords $[3,4]$.

The immature Sertoli cell differs extensively from the mature cell with respect to both morphology and biochemical activity. The structure of the immature seminiferous tubule (cord) also differs, containing in addition to Sertoli cells, only peritubular and germ stem cells (spermatogonia). Germ cell differentiation has not yet begun and the seminiferous cords are solid, lacking any lumen (fig. 1A).

As puberty approaches, the Sertoli cells become elongated and tight junctions are established between them. These cells begin to produce seminiferous fluid, which results in the transformation of the testis cords into seminiferous tubules possessing a lumen. The differentiated, mature Sertoli cell alters its pattern of protein expression, starting to produce, e.g., transferrin [5] and the inflammatory cytokine IL-1 $\alpha$ [6-9] (table 1). Immature Sertoli cells divide constantly, but this proliferative activity declines in connection with puberty and after tight junctions have been formed, Sertoli cells are considered to no longer exhibit proliferative capacity [10]. These pronounced differences between the immature and mature Sertoli cell indicate that it is as important to understand the differentiation process as to characterize the functional regulation of the mature cells.

\section{Sertoli Cell Function}

Clearly, adequate Sertoli cell function is required for the appropriate differentiation of germ cells (fig. 2). Unfortunately, even though many of the proteins expressed by Sertoli cells have been identified, in the vast majority of cases the specific role played by each protein in connection with germ cell development remains unknown. The most convincing evidence that an individual factor produced by Sertoli cells is crucial for spermatogenesis concerns the stem cell factor, which is produced exclusively by these cells in the tubules and for which the receptor c-kit is expressed on spermatogonia. Although functional disruption of either stem cell factor or c-kit in the mouse results in germ cell depletion, the implications of this finding for human testicular disorders is not yet clear (for a review see [11]). 
Fig. 1. Schematic illustration of testicular morphology. The different cell types are color-coded as indicated. A The immature testis. The solid seminiferous cords consist of immature Sertoli cells, peritubular cells and spermatogonia (stem cells). B The mature testis. The seminiferous tubules have a lumen and are filled with differentiating germ cells. The Sertoli cells are elongated with crypts and attached to one another with tight junctions (the blood-testis barrier).

Fig. 2. The paracrine role of the Sertoli cell. Sertoli cells produce steroids and nutrients, together with a large number of proteins that may regulate germ cell growth and survival. These products may be secreted in a biphasic manner, i.e., either above the blood-testis barrier to act on haploid germ cells or below this barrier to influence cells located in the interstitium, e.g., the Leydig cells. IGF-I = Insulin-like growth factor-I; FGF = fibroblast growth factor; IL- $1 \alpha=$ interleukin- $1 \alpha$; TGF- $\alpha / \beta=$ transforming growth factor- $\alpha / \beta$; SCF $=$ stem cell factor. The different cell types are color-coded as indicated. For additional information, see $[97,98]$.
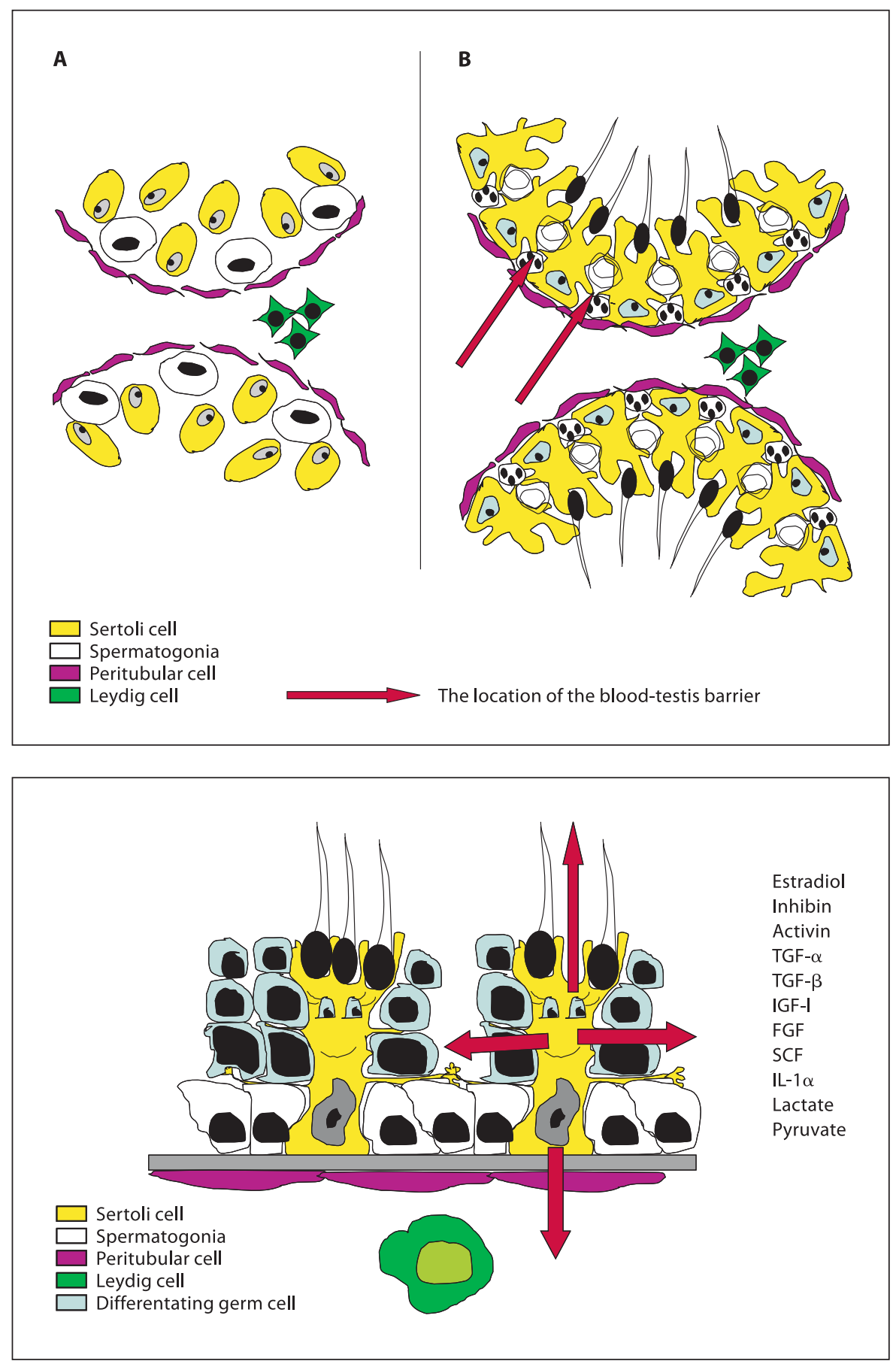

Following disruption of the extracellular matrix by enzymatic digestion, Sertoli cells can be isolated and thereafter cultured and studied in vitro. However, due to the presence of tight junctions and other changes in the cell membrane following puberty, such isolation is difficult to perform on adult testes. In vitro investigations of
Sertoli cell function focus primarily on the influence of various endocrine and paracrine factors on the expression and activity of certain proteins that can be assayed easily, e.g., transferrin, aromatase, the androgen receptor (AR) and lactate dehydrogenase. 


\section{Endocrine Regulation}

\section{Follicle-Stimulating Hormone}

FSH is the major endocrine hormone known to regulate Sertoli cell function. This is the only cell type in the testis that expresses receptors for this hormone, which, in combination with other factors $[12,13]$, is well established to be required for adequate Sertoli cell proliferation $[14,15]$. Moreover, FSH stimulates the aromatase activity and production of, e.g., inhibin, lactate, transferrin and AR by Sertoli cells [16-19]. Humans who lack a functional FSH receptor develop smaller testes than do normal males, in agreement with the reduction in Sertoli cell number observed in the testes of mice lacking this receptor [20]. These men also exhibit disturbed spermatogenesis (oligozoopermia and teratozoopermia), although they remain fertile [21].

Thyroid Hormone and Thyroid-Stimulating Hormone

A number of investigations on experimental animals have established that hypothyroidism prolongs the phase of Sertoli cell proliferation, i.e., inhibits the differentiation of these cells, resulting in elevated Sertoli cell number, testis size and sperm count [22-24]. Conversely, high levels of T3 enhance differentiation and give rise to smaller testes and a lower sperm count. Although, the effects of high levels of TSH per se have not been characterized in detail, it is shown that high levels of TSH may interact with the FSH receptor [25], thus offering a plausible explanation for the enhanced proliferation of immature Sertoli cells observed in connection with experimental hypothyrodism. In humans, hypothyroidism may be associated with increased testis volume (macroorchidism) in the absence of precocious puberty, indicating the presence of an elevated number of Sertoli cells [26].

\section{Prolactin}

It is a well-known fact that elevated levels of prolactin (PRL) impair fertility in both males and females by inhibiting secretion of gonadotrophins. Sertoli cells express PRL receptors [27] and this hormone stimulates cell growth, lactate secretion and general protein synthesis by both rat and porcine Sertoli cells [28]. Targeted disruption of either PRL or its receptor in male mice does not affect their fertility, indicating that PRL does not play an essential role in maintaining male reproductive health (for a review see [29]). Moreover, no cases of human testicular pathology linked to inactivating mutations in the genes encoding PRL or its receptor have been reported.

\section{Growth Hormone}

Convincing evidence demonstrates that growth hormone $(\mathrm{GH})$ and insulin-like growth factor (IGF)-I, produced systemically and/or locally, interfere with gonadal function. Sertoli cells express GH receptors [30]; systemic administration of GH in boars' results in enhanced Sertoli cell size and maturation [31], and failure to respond to GH results in delayed sexual maturation but no impairment of fertility [32]. Moreover, a deficiency in GH may be associated with the development of smaller testes, indicating a reduction in the number of Sertoli cells, although again fertility is not compromised [33]. To date, no in vitro studies have confirmed that these effects observed in vivo reflect a direct receptor-mediated influence on Sertoli cells.

GH treatment in boys without GH deficiency is reported to impair testicular function and reduce testicular size [34], but other reports do not support this finding $[35,36]$.

\section{Paracrine Regulation}

\section{Testosterone}

Spermatogenesis is dependent on the presence of an adequate intratesticular level of testosterone [37]. Sertoli cells express the AR, but germ cells do not [38], indicating that androgenic effects on the seminiferous epithelium are mediated via the former. Recently, cell-specific targeting of the expression of AR by Sertoli cells, confirmed that this receptor is required for an adequate blood-testis barrier function [39] as well as for meiosis and the postmeiotic development of germ cells [40]. The level of expression of AR on Sertoli cells increases in connection with maturation [41]. However, even though androgenic action on these cells modulates their gene expression and proliferation [40, 42], it has still not been conclusively established that such action is crucial to early differentiation of the Sertoli cell [40]. There are several case reports on patients with null mutations of $A R$ and Sertoli cell tumors (though the most common histological form of tumor is seminoma) [43] and even in the absence of tumor tissue the Sertoli cells from these patients have been described as having immature features [44].

\section{Estrogen}

Possible estrogenic action on the testis has been the subject of a great deal of debate in recent years. It has long been known that prenatal exposure of males to estrogens 
adversely affects their later fertility [45], but the discovery that testicular cells express estrogen receptors indicated that estrogenic action on the testis may be of physiological relevance [46, 47]. Immature Sertoli cells may themselves produce estrogens via their aromatase activity [48], whereas in adulthood Leydig and germ cells become sources of testicular estrogen [49].

Sertoli cells express the estrogen receptor- $\beta$ (ER- $\beta$ ) throughout the process of maturation and may thus respond to estrogens from an early age onwards [50]. Although no clear evidence that these cells require estrogens to function adequately exists, testicular function in human males possessing either a disrupted aromatase gene or non-functional estrogen receptor has been reported to be disturbed [51]. Moreover, male mice lacking a functional aromatase gene exhibit normal sexual development and are initially fertile, but later become infertile [52].

\section{Growth Factors}

The large number of growth factors that have been isolated from the testis include fibroblast growth factors1 and -2 (FGF-1, FGF-2), insulin-like growth factors I and II (IGF-I, IGF-II), transforming growth factor- $\alpha$ (TGF$\alpha$ ), activin A and epidermal growth factor (EGF). Receptors for most of these growth factors are present on Sertoli cells [53-57] and several of them, i.e., FGF-2, IGF-I, IGF-II, TGF- $\alpha$, EGF, activin A, have been found to stimulate the growth of these cells, although contradictory reports have also appeared [13,58-63]. A number of these growth factors also appear to influence other Sertoli cell functions, such as the production of lactate and transferrin (for a review, see [64]).

No gene mutations in humans that might provide insight into the biological relevance for gonadal function of these in vitro findings have yet been described. Furthermore, since these growth factors have pronounced effects on other organ systems as well, findings on 'knock-out' mice must be interpreted with care. At present, it appears likely that paracrine growth factors play a role in the growth and maturation of Sertoli cells, but that redundancy ensures that these processes are not wholly dependent on any single one of these factors.

\section{Inhibin B}

Sertoli cells produce and secrete the peptide hormone inhibin B into the circulation as a response to FSH stimulation. Inhibin B is generally considered to play an endocrine role by inhibiting FSH-secretion from the pituitary and there is no clear evidence of any autocrine ef- fects of the hormone on the Sertoli cells themselves. In humans, serum inhibin B-levels are high during early postnatal life and then gradually declines to a still detectable plateau-level until puberty when the levels again increase. Measurements of inhibin B is clinically used to assess the presence and function of Sertoli cells during childhood. In contrast, the inhibin B levels in adult life are dependent on the presence of germ cells and thus reflect spermatogenesis $[63,65]$.

\section{Inflammatory Cytokines}

The expression of proinflammatory cy tokines is readily induced in activated macrophages in response to inflammatory stimuli and in vitro Sertoli cells clearly respond to several of these cytokines.

Expression of the major products of activated macrophages, interleukin-1 (IL-1), tumor necrosis factor- $\alpha$ (TNF- $\alpha$ ) and interleukin-6 (IL-6), is also easily induced in Sertoli cells by procedures employed for cell isolation [66-68], a fact which is important to remember when evaluating findings on primary cell cultures.

IL- $1 \alpha$ is produced constitutively by Sertoli cells in the testis from the beginning of puberty $[7-9,69,70]$, whereas testicular production of IL- $1 \beta$ may be induced by proinflammatory stimuli [71]. Sertoli cells also express IL-1 receptors [72] and both IL- $1 \alpha$ and IL-1 $\beta$ influence various Sertoli cell functions, including the production of transferrin and lactate $[73,74]$. Furthermore, IL-1 acts as a potent growth factor for Sertoli cells in vitro [67].

Although TNF- $\alpha$ has been reported to be expressed by germ cells even under non-inflammatory conditions [75], its production is potently enhanced by proinflammatory stimuli, as is the case for other cytokines [76]. TNF- $\alpha$ enhances transferrin secretion by Sertoli cells [77], as well as inhibiting their aromatase activity and production of lactate and inhibin [78].

Although it is clear that testicular IL- 6 production can be induced by inflammatory stimuli, both in vivo and in vitro [76, 79], this cytokine is not normally expressed in the rat testis [7]. Isolated Sertoli cells respond to IL- 6 by elevating their production of transferrin [80], as well as reducing secretion of this protein [77].

Our own studies have demonstrated that IL- $1 \alpha$, IL-1 $\beta$, TNF- $\alpha$ and IL- 6 all stimulate the growth of immature Sertoli cells in culture $[67,68]$.

The possible physiological relevance of testicular IL$1 \alpha$ and TNF- $\alpha$ under non-inflammatory conditions remains obscure. Mice in which the IL-1 or TNF receptors have been disrupted exhibit no alteration in testicular phenotype $[81,82]$ and no relevant mutations in humans 
Table 2. Some substances that exert toxic effects on Sertoli cells*

\begin{tabular}{ll}
\hline Substance & Target \\
\hline Cisplatin & Blood-testis barrier \\
Colchicine & Blood-testis barrier \\
Cytochalasin D & Blood-testis barrier \\
Nitroaromatic compounds & Sertoli cell metabolism \\
Phtalates & Sertoli cell metabolism and \\
& proliferation \\
\hline
\end{tabular}

* For references, see $[90,91]$.

have been reported to be associated with testicular pathology. On the other hand, inflammatory cytokines may act well as pathogenetic factors in connection with testicular damage of various kinds.

\section{The Number of Sertoli Cells Present Determines Sperm Output and Testicular Size}

Investigations on fish have revealed clearly that one individual Sertoli cell nurses a clone of developing germ cells [83]. Furthermore, the correlation between Sertoli cell number and both testicular size and sperm output is well established [84]. Sertoli cells divide rapidly and extensively during fetal and early postnatal life, after which their mitotic activity is attenuated. At the beginning of puberty, these cells stop proliferating altogether and thereafter their number is considered to be fixed $[10,85]$. Consequently, it is important for future fertility to establish an adequate number of Sertoli cells during prepubertal life. It is worth noting that the cytostatic drug cytosine arabinoside (AraC), employed clinically in several modern protocols for treatment of childhood cancer, blocks Sertoli cell proliferation in experimental systems [84].

\section{Involvement of Sertoli Cells in Testicular Pathology}

Indications that not only male gonadal malformations (e.g., hypospadia and cryptorchidism), but also reduced sperm counts and the development of testicular cancer later in life may result from processes occurring during fetal/early postnatal life have stimulated research interest in the immature testis, and particularly Sertoli cells. Poorly developed Sertoli cells, exhibiting morphological features characteristic of immature cells, have been ob- served in human testes demonstrating spermatogenic dysfunction or cryptorchidism, as well as in the close vicinity of testicular cancer [86], suggesting possible pathogenetic involvement of Sertoli cells in these conditions.

The incidence of TDS appears to be increasing (for references, see [2]). There are geographical variations; e.g., Finland has a lower incidence of testicular cancer than Denmark, but both of these countries still share in the same rising trend. Thus, in Finland the incidence of testicular cancer has increased from 1.3 to 3.2 and in Denmark from 7.8 to 10.3 per 100,000 inhabitant-years during the last 20 years $[87,88]$.

It has been speculated that environmental agents, socalled endocrine disrupters which may potentially interfere with physiological hormonal events early in life, are involved in such increases [2]. Indeed, administration of the synthetic estrogen diethylstilboestrol to rats decreases the number of Sertoli cells [42], also disturbing their maturation and thereby delaying, e.g., the formation of the blood-testis barrier [89]. It has been recognized for some time that Sertoli cells are the targets of various toxicants, which harm testicular functions (table 2) [90], e.g., a group of plasticizers known as phthalates, which are wide spread in the environment including children's toys and soft plastics used in health care products have actually been shown to cause effects resembling those of TDS in rats [91].

It is also known that perinatal risk factors may be involved in the pathogenesis of testicular cancer. Numerous reports demonstrate that both premature birth and a low birth weight significantly increase the risk for future development of testicular malignancy [92-95]. Thus, events that are not strictly hormonal may be of importance in this connection, especially in the light of the fact that severe infections, exposure to drugs and other stressful events often disrupt the early life of premature infants.

\section{Concluding Remarks}

Somatic Sertoli cells located in the seminiferous epithelium of the testis are of central importance in connection with early determination of male somatic sex as well as germ cell development during adult life. The number of Sertoli cells present correlates well with the size of the testis and accordingly with the adult number of germ cells produced. Prior to the start of puberty, Sertoli cells continue to divide and mature. Several investigations have focused on hormonal regulation of the functions of 
the differentiated cells, but the detailed mechanisms underlying the maturation process and general maintenance of a well-functioning Sertoli cell remain obscure.

The alarming decline in male reproductive health challenges researchers to attempt to characterize harmful effects of environmental agents on the testis during fetal and early neonatal life. Poor differentiation of Sertoli cells is thought to be involved in the processes leading to a low sperm count, as well as to testicular cancer. Even though efforts have been made to elucidate the endocrine and paracrine regulation of the Sertoli cell, many questions remain to be answered before definitive conclusions concerning environmental influences on the immature Sertoli cell can be drawn.

\section{References}

1 Russell LD, Griswold MD: The Sertoli Cell. Clearwater, Cache River Press, 1993.

-2 Skakkebaek NE, Rajpert-De Meyts E, Main KM: Testicular dysgenesis syndrome: an increasingly common developmental disorder with environmental aspects. Hum Reprod 2001;16:972-978.

3 Griswold MD: The central role of Sertoli cells in spermatogenesis. Semin Cell Dev Biol 1998;9:411-416.

4 McLaren A: Germ and somatic cell lineages in the developing gonad. Mol Cell Endocrinol 2000;163:3-9.

5 Skinner MK, Griswold MD: Sertoli cells synthesize and secrete transferrin-like protein. J Biol Chem 1980;255:9523-9525.

-6 Syed V, Söder O, Arver S, Lindh M, Khan S, Ritzen EM: Ontogeny and cellular origin of an interleukin-1-like factor in the reproductive tract of the male rat. Int J Androl 1988; 11:437-447.

7 Jonsson CK, Zetterström RH, Holst M, Parvinen M, Söder O: Constitutive expression of interleukin-1alpha messenger ribonucleic acid in rat Sertoli cells is dependent upon interaction with germ cells. Endocrinology 1999;140:3755-3761.

8 Wahab-Wahlgren A, Holst M, Ayele D, Sultana T, Parvinen M, Gustafsson K, Granholm T, Söder O: Constitutive production of interleukin-1alpha mRNA and protein in the developing rat testis. Int J Androl 2000;23: 360-365.

-9 Sultana T, Svechnikov K, Weber G, Söder O: Molecular cloning and expression of a functionally different alternative splice variant of prointerleukin-1alpha from the rat testis. Endocrinology 2000;141:4413-4418.

- 10 Steinberger A, Steinberger E: Replication pattern of Sertoli cells in maturing rat testis in vivo and in organ culture. Biol Reprod 1971;4:84-87.

$\checkmark 11$ Mauduit C, Hamamah S, Benahmed M: Stem cell factor/c-kit system in spermatogenesis. Hum Reprod Update 1999;5:535545.

-12 Boitani C, Stefanini M, Fragale A, Morena AR: Activin stimulates Sertoli cell proliferation in a defined period of rat testis development. Endocrinology 1995;136:5438-5444.
Petersen C, Boitani C, Fröysa B, Söder O: Transforming growth factor- $\alpha$ stimulates proliferation of rat Sertoli cells. Mol Cell Endocrinol 2001;181:221-227.

14 Griswold MD, Solari A, Tung PS, Fritz IB: Stimulation by follicle-stimulating hormone of DNA synthesis and of mitosis in cultured Sertoli cells prepared from testes of immature rats. Mol Cell Endocrinol 1977;7:151165.

15 Orth JM, Higginbotham CA, Salisbury RL: Hemicastration causes and testosterone prevents enhanced uptake of $[3 \mathrm{H}]$ thymidine by Sertoli cells in testes of immature rats. Biol Reprod 1984;30:263-270.

16 Bicsak TA, Vale W, Vaughan J, Tucker EM, Cappel S, Hsueh AJ: Hormonal regulation of inhibin production by cultured Sertoli cells. Mol Cell Endocrinol 1987;49:211-217.

17 Mita M, Price JM, Hall PF: Stimulation by follicle-stimulating hormone of synthesis of lactate by Sertoli cells from rat testis. Endocrinology 1982;110:1535-1541.

18 Skinner MK, Schlitz SM, Anthony CT: Regulation of Sertoli cell differentiated function: testicular transferrin and androgen-binding protein expression. Endocrinology 1989; 124:3015-3024.

19 Verhoeven G, Cailleau J: Follicle-stimulating hormone and androgens increase the concentration of the androgen receptor in Sertoli cells. Endocrinology 1988;122:15411550.

20 Dierich A, Sairam MR, Monaco L, Fimia GM, Gansmuller A, LeMeur M, SassoneCorsi P: Impairing follicle-stimulating hormone (FSH) signaling in vivo: targeted disruption of the FSH receptor leads to aberrant gametogenesis and hormonal imbalance. Proc Natl Acad Sci USA 1998;95:1361213617.

21 Tapanainen JS, Aittomaki K, Min J, Vaskivuo T, Huhtaniemi IT: Men homozygous for an inactivating mutation of the follicle-stimulating hormone (FSH) receptor gene present variable suppression of spermatogenesis and fertility. Nat Genet 1997;15:205-206.
22 Van Haaster LH, De Jong FH, Docter R, De Rooij DG: The effect of hypothyroidism on Sertoli cell proliferation and differentiation and hormone levels during testicular development in the rat. Endocrinology 1992;131: 1574-1576.

23 Cooke PS, Meisami E: Early hypothyroidism in rats causes increased adult testis and reproductive organ size but does not change testosterone levels. Endocrinology 1991;129: 237-243.

24 van Haaster LH, de Jong FH, Docter R, de Rooij DG: High neonatal triiodothyronine levels reduce the period of Sertoli cell proliferation and accelerate tubular lumen formation in the rat testis, and increase serum inhibin levels. Endocrinology 1993; 133: 755-760.

25 Anasti JN, Flack MR, Froehlich J, Nelson LM, Nisula BC: A potential novel mechanism for precocious puberty in juvenile hypothyroidism. J Clin Endocrinol Metab 1995;80:276-279.

26 Weber G, Vigone MC, Stroppa L, Chiumello G: Thyroid function and puberty. J Pediatr Endocrinol Metab 2003;16(suppl 2):253257.

27 Guillaumot P, Benahmed M: Prolactin receptors are expressed and hormonally regulated in rat Sertoli cells. Mol Cell Endocrinol 1999;149:163-168.

28 Scarabelli L, Caviglia D, Bottazzi C, Palmero S: Prolactin effect on pre-pubertal Sertoli cell proliferation and metabolism. J Endocrinol Invest 2003;26:718-722.

29 Huhtaniemi I, Bartke A: Perspective: male reproduction. Endocrinology 2001; 142: 2178-2183.

30 Gomez JM, Loir M, Le Gac F: Growth hormone receptors in testis and liver during the spermatogenetic cycle in rainbow trout (Oncorhynchus mykiss). Biol Reprod 1998;58: 483-491.

31 Swanlund DJ, N'Diaye MR, Loseth KJ, Pryor JL, Crabo BG: Diverse testicular responses to exogenous growth hormone and folliclestimulating hormone in prepubertal boars. Biol Reprod 1995;53:749-757.

-32 Laron Z: Growth hormone insensitivity (Laron syndrome). Rev Endocr Metab Disord 2002;3:347-355. 
-33 Bartlett JM, Charlton HM, Robinson IC, Nieschlag E: Pubertal development and testicular function in the male growth hormonedeficient rat. J Endocrinol 1990;126: 193-201.

- 34 Bertelloni S, Baroncelli GI, Viacava P, Massimetti M, Simi P, Saggese G: Can growth hormone treatment in boys without growth hormone deficiency impair testicular function? J Pediatr 1999;135:367-370.

- 35 Ankarberg-Lindgren C, Norjavaara E, Wikland KA: Short boys treated with growth hormone show normal progression of testicular size and achieve normal serum testosterone concentrations. Eur J Endocrinol 2002;146:681-685.

- 36 Lindgren AC, Chatelain P, Lindberg A, Price DA, Ranke MB, Reiter EO, Wilton P: Normal progression of testicular size in boys with idiopathic short stature and isolated growth hormone deficiency treated with growth hormone: experience from the KIGS. Horm Res 2002;58:83-87.

- 37 Russell LD, Clermont Y: Degeneration of germ cells in normal, hypophysectomized and hormone treated hypophysectomized rats. Anat Rec 1977;187:347-366.

- 38 Lyon MF, Glenister PH, Lamoreux ML: Normal spermatozoa from androgen-resistant germ cells of chimaeric mice and the role of androgen in spermatogenesis. Nature 1975; 258:620-622.

- 39 Meng J, Holdcraft RW, Shima JE, Griswold $\mathrm{MD}$, Braun RE: Androgens regulate the permeability of the blood-testis barrier. Proc Natl Acad Sci USA 2005; 102:16696-16700.

-40 Tan KA, De Gendt K, Atanassova N, Walker M, Sharpe RM, Saunders PT, Denolet E, Verhoeven G: The role of androgens in sertoli cell proliferation and functional maturation: studies in mice with total or Sertoli cell-selective ablation of the androgen receptor. Endocrinology 2005; 146:2674-2683.

-41 Buzek SW, Sanborn BM: Increase in testicular androgen receptor during sexual maturation in the rat. Biol Reprod 1988;39:39-49.

-42 Atanassova NN, Walker M, McKinnell C, Fisher JS, Sharpe RM: Evidence that androgens and oestrogens, as well as follicle-stimulating hormone, can alter Sertoli cell number in the neonatal rat. J Endocrinol 2005; 184:107-117.

43 Wysocka B, Serkies K, Debniak J, Jassem J, Limon J: Sertoli cell tumor in androgen insensitivity syndrome - a case report. Gynecol Oncol 1999;75:480-483.

-44 Aumuller G, Peter S: Immunohistochemical and ultrastructural study of Sertoli cells in androgen insensitivity. Int J Androl 1986;9: 99-108.

-45 Stillman RJ: In utero exposure to diethylstilbestrol: adverse effects on the reproductive tract and reproductive performance and male and female offspring. Am J Obstet Gynecol 1982;142:905-921.
46 Aschim EL, Saether T, Wiger R, Grotmol T, Haugen TB: Differential distribution of splice variants of estrogen receptor beta in human testicular cells suggests specific functions in spermatogenesis. J Steroid Biochem Mol Biol 2004;92:97-106.

47 Carreau S: The testicular aromatase: from gene to physiological role. Reprod Biol 2002; 2:5-12.

48 Rommerts FF, de Jong FH, Brinkmann AO, van der Molen HJ: Development and cellular localization of rat testicular aromatase activity. J Reprod Fertil 1982;65:281-288.

49 Carreau S, Genissel C, Bilinska B, Levallet J: Sources of oestrogen in the testis and reproductive tract of the male. Int J Androl 1999; 22:211-223.

50 Saunders PT, Fisher JS, Sharpe RM, Millar MR: Expression of oestrogen receptor beta (ER beta) occurs in multiple cell types, including some germ cells, in the rat testis. J Endocrinol 1998;156:R13-R17.

51 Smith EP, Boyd J, Frank GR, Takahashi H, Cohen RM, Specker B, Williams TC, Lubahn DB, Korach KS: Estrogen resistance caused by a mutation in the estrogen-receptor gene in a man. N Engl J Med 1994;331:10561061.

52 Robertson KM, O’Donnell L, Jones ME, Meachem SJ, Boon WC, Fisher CR, Graves $\mathrm{KH}$, McLachlan RI, Simpson ER: Impairment of spermatogenesis in mice lacking a functional aromatase (cyp 19) gene. Proc Natl Acad Sci USA 1999;96:7986-7991.

53 Koike S, Noumura T: Immunohistochemical localization of insulin-like growth factor-II in the perinatal rat gonad. Growth Regul 1995;5:185-189.

54 Caussanel V, Tabone E, Mauduit C, Dacheux $\mathrm{F}$, Benahmed M: Cellular distribution of EGF, TGFalpha and their receptor during postnatal development and spermatogenesis of the boar testis. Mol Cell Endocrinol 1996; 123:61-69.

55 Cancilla B, Davies A, Ford-Perriss M, Risbridger GP: Discrete cell- and stage-specific localisation of fibroblast growth factors and receptor expression during testis development. J Endocrinol 2000;164:149-159.

56 Cupp AS, Skinner MK: Expression, action, and regulation of transforming growth factor alpha and epidermal growth factor receptor during embryonic and perinatal rat testis development. J Androl 2001;22:1019-1029.

57 Handelsman DJ, Spaliviero JA, Scott CD, Baxter RC: Identification of insulin-like growth factor-I and its receptors in the rat testis. Acta Endocrinol (Copenh) 1985;109: 543-549.

58 Borland K, Mita M, Oppenheimer CL, Blinderman LA, Massague J, Hall PF, Czech MP: The actions of insulin-like growth factors I and II on cultured Sertoli cells. Endocrinology 1984;114:240-246.
59 Jaillard C, Chatelain PG, Saez JM: In vitro regulation of pig Sertoli cell growth and function: effects of fibroblast growth factor and somatomedin-C. Biol Reprod 1987;37: 665-674.

60 Le Magueresse-Battistoni B, Wolff J, Morera AM, Benahmed M: Fibroblast growth factor receptor type 1 expression during rat testicular development and its regulation in cultured Sertoli cells. Endocrinology 1994;135: 2404-2411.

61 Cancilla B, Risbridger GP: Differential localization of fibroblast growth factor receptor$1,-2,-3$, and -4 in fetal, immature, and adult rat testes. Biol Reprod 1998;58:1138-1145.

62 Mullaney BP, Skinner MK: Transforming growth factor-alpha and epidermal growth factor receptor gene expression and action during pubertal development of the seminiferous tubule. Mol Endocrinol 1992;6:21032113.

-63 de Kretser DM, Buzzard JJ, Okuma Y, O'Connor AE, Hayashi T, Lin SY, Morrison JR, Loveland KL, Hedger MP: The role of activin, follistatin and inhibin in testicular physiology. Mol Cell Endocrinol 2004;225: 57-64.

64 Mullaney BP, Skinner MK: Growth factors as mediators of testicular cell-cell interactions. Baillieres Clin Endocrinol Metab 1991;5: 771-790.

65 Andersson AM, Skakkebaek NE: Serum inhibin B levels during male childhood and puberty. Mol Cell Endocrinol 2001;180:103107.

66 Hales DB, Diemer T, Hales KH: Role of cytokines in testicular function. Endocrine 1999; 10:201-217.

67 Petersen C, Boitani C, Fröysa B, Söder O: Interleukin-1 is a potent growth factor for immature rat Sertoli cells. Mol Cell Endocrinol 2002;186:37-47.

68 Petersen C, Fröysa B, Söder O: Endotoxin and proinflammatory cytokines modulate Sertoli cell proliferation in vitro. J Reprod Immunol 2004;61:13-30.

69 Khan SA, Söder O, Syed V, Gustafsson K, Lindh M, Ritzen EM: The rat testis produces large amounts of an interleukin-1-like factor. Int J Androl 1987;10:495-503.

70 Gustafsson K, Sultana T, Zetterstrom CK, Setchell BP, Siddiqui A, Weber G, Soder O: Production and secretion of interleukin-1alpha proteins by rat testis. Biochem Biophys Res Commun 2002;297:492-497.

71 Jonsson CK, Setchell BP, Martinelle N, Svechnikov K, Söder O: Endotoxin-induced interleukin-1 expression in testicular macrophages is accompanied by down-regulation of the constitutive expression in Sertoli cells. Cytokine 2001;14:283-288.

72 Gomez E, Morel G, Cavalier A, Lienard MO, Haour F, Courtens JL, Jegou B: Type I and type II interleukin-1 receptor expression in rat, mouse, and human testes. Biol Reprod 1997;56:1513-1526. 
73 Karzai AW, Wright WW: Regulation of the synthesis and secretion of transferrin and cyclic protein-2/cathepsin L by mature rat Sertoli cells in culture. Biol Reprod 1992;47: 823-831.

-74 Nehar D, Mauduit C, Boussouar F, Benahmed M: Interleukin 1alpha stimulates lactate dehydrogenase A expression and lactate production in cultured porcine sertoli cells. Biol Reprod 1998;59:1425-1432.

75 De SK, Chen HL, Pace JL, Hunt JS, Terranova PF, Enders GC: Expression of tumor necrosis factor-alpha in mouse spermatogenic cells. Endocrinology 1993;133:389-396.

-76 Jonsson C, Setchell BP, Sultana T, Holst M, Parvinen M, Soder O: Constitutive and inducible production of proinflammatory cytokines by the rat testis. Andrologia 2000;32: 63-64.

-77 Boockfor FR, Schwarz LK: Effects of interleukin-6, interleukin-2, and tumor necrosis factor alpha on transferrin release from Sertoli cells in culture. Endocrinology 1991;129: 256-262.

78 Mauduit C, Jaspar JM, Poncelet E, Charlet C, Revol A, Franchimont P, Benahmed M: Tumor necrosis factor-alpha antagonizes follicle-stimulating hormone action in cultured Sertoli cells. Endocrinology 1993;133:6976.

79 Stephan JP, Syed V, Jegou B: Regulation of Sertoli cell IL-1 and IL- 6 production in vitro. Mol Cell Endocrinol 1997;134:109-118.

-80 Hoeben E, Wuyts A, Proost P, Van Damme J, Verhoeven G: Identification of IL- 6 as one of the important cytokines responsible for the ability of mononuclear cells to stimulate Sertoli cell functions. Mol Cell Endocrinol 1997;132:149-160.
-81 Cohen PE, Pollard JW: Normal sexual function in male mice lacking a functional type I interleukin-1 (IL-1) receptor. Endocrinology 1998;139:815-818.

82 Acton RD, Dahlberg PS, Uknis ME, Klaerner HG, Fink GS, Norman JG, Dunn DL: Differential sensitivity to Escherichia coli infection in mice lacking tumor necrosis factor p55 or interleukin-1 p80 receptors. Arch Surg 1996;131:1216-1221.

83 Dubois W, Callard GV: Shark testis model: stage-dependent functions and the regulation of spermatogenesis. J Exp Zool Suppl 1990;4:142-144.

84 Orth JM, Gunsalus GL, Lamperti AA: Evidence from Sertoli cell-depleted rats indicates that spermatid number in adults depends on numbers of Sertoli cells produced during perinatal development. Endocrinology 1988;122:787-794.

85 Cortes D, Muller J, Skakkebaek NE: Proliferation of Sertoli cells during development of the human testis assessed by stereological methods. Int J Androl 1987;10:589-596.

86 Sharpe RM, McKinnell C, Kivlin C, Fisher JS: Proliferation and functional maturation of Sertoli cells, and their relevance to disorders of testis function in adulthood. Reproduction 2003;125:769-784.

87 Adami HO, Bergstrom R, Mohner M, Zatonski W, Storm H, Ekbom A, Tretli S, Teppo L, Ziegler H, Rahu M, et al: Testicular cancer in nine northern European countries. Int J Cancer 1994;59:33-38.

88 GLOBOCAN 2002; http://www-dep.iarc.fr/

89 Toyama Y, Ohkawa M, Oku R, Maekawa M, Yuasa S: Neonatally administered diethylstilbestrol retards the development of the blood-testis barrier in the rat. J Androl 2001; 22:413-423
90 Boekelheide K: Sertoli cell toxicants; in Russell LD, Griswold MD (eds): The Sertoli Cell. Clearwater, Cache River Press, 1993, pp 551575.

91 Fisher JS, Macpherson S, Marchetti N, Sharpe RM: Human 'testicular dysgenesis syndrome': a possible model using in-utero exposure of the rat to dibutyl phthalate. Hum Reprod 2003;18:1383-1394.

$\checkmark 92$ Depue RH, Pike MC, Henderson BE: Cryptorchidism and testicular cancer. J Natl Cancer Inst 1986;77:830-833.

$\checkmark 93$ Moller H, Skakkebaek NE: Testicular cancer and cryptorchidism in relation to prenatal factors: case-control studies in Denmark. Cancer Causes Control 1997;8:904-912.

94 Sabroe S, Olsen J: Perinatal correlates of specific histological types of testicular cancer in patients below 35 years of age: a case-cohort study based on midwives' records in Denmark. Int J Cancer 1998;78:140-143.

95 Richiardi L, Akre O, Bellocco R, Ekbom A: Perinatal determinants of germ-cell testicular cancer in relation to histological subtypes. Br J Cancer 2002;87:545-550.

96 Andersson AM, Muller J, Skakkebaek NE: Different roles of prepubertal and postpubertal germ cells and Sertoli cells in the regulation of serum inhibin B levels. J Clin Endocrinol Metab 1998;83:4451-4458.

97 Jegou B: The Sertoli-germ cell communication network in mammals. Int Rev Cytol 1993;147:25-96.

98 Schlatt S, Meinhardt A, Nieschlag E: Paracrine regulation of cellular interactions in the testis: factors in search of a function. Eur J Endocrinol 1997;137:107-117. 